\title{
COXEN Score 11
}

National Cancer Institute

\section{Source}

National Cancer Institute. COXEN Score 11. NCI Thesaurus. Code C128208.

A score of 11 on the COXEN Sensitivity Scale. 